\title{
RADIAL GROWTH AND HEALTH CONDITION OF NORWAY SPRUCE (PICEA ABIES (L.) KARST.) STANDS IN RELATION TO CLIMATE (SILESIAN BESKIDS, CZECH REPUBLIC)
}

\author{
MICHAL RYBNÍČEK, PETR ČERMÁK, TOMÁŠ ŽID and TOMÁŠ KOLÁ̌̌ \\ Mendel University in Brno, Faculty of Forestry and Wood Technology, \\ Zemédělská 3, 61300 Brno, Czech Republic
}

Received 5 July 2010

Accepted 2 September 2010

\begin{abstract}
The research was conducted in selected spruce stands of the Silesian Beskids aged over 70 at altitudes from $403 \mathrm{~m}$ a.s.1. to $794 \mathrm{~m}$ a.s.l. in 2008. The samples were taken and processed in compliance with standard dendrochronological methodology. Tree rings were measured and the treering curves were synchronized using the PAST4 application. The age trend was removed in the ARSTAN application and the climatic influences were modelled in the DendroClim application. The regional standard tree-ring chronology shows an obvious decrease in the radial increment from the beginning of the 1970s to the mid-1990s. The gradual increase in radial increment which followed in the second half of the 1990s was interrupted in 2000, 2003, and 2006. Most of the years with the decreased radial increment have been confirmed by the analysis of significant negative years. The radial increment statistically significantly correlates with the precipitation in July and September of the previous year, precipitation in June of the year in question and precipitation during the vegetation period. Moreover, the growth of spruce is statistically significantly affected by temperatures in October of the previous year and March of the year in question. Additionally, the paper includes habitual monitoring of trees and the volume of salvage cutting in these districts. The condition of the habit of trees and the development of salvage cuttings agree with the hypothesis about strong stress load or its considerable increase in 2003 and the following years.
\end{abstract}

Keywords: the Silesian Beskids, spruce, precipitation, temperature, tree-ring, habitual diagnostic.

\section{INTRODUCTION}

Norway spruce (Picea abies (L.) Karst.) is one of the most significant European tree species and also a tree species with the highest number of various health and growth problems which have appeared in the last decades. It has quite specific requirements concerning precipitation and generally it is one of the species that are quite sensitive to the climate. The relation between the climate and radial increment has recently been explored by e.g. Mäkinen et al. (2000, 2001, 2002), Vitas (2004), Koprowski and Zielski (2006), Savva et al. (2006), Büntgen et al. (2007).

At the beginning of this century, signs of Picea abies decline started to appear in the Silesian Beskids, espe-

Corresponding author: M. Rybníček

e-mail: michalryb@email.cz cially in forest district Jablunkov. The Polish side of the Silesian Beskids had already seen this decline at the beginning of the 1990s. The decline has a character of a complex disease brought about by synergic influence of abiotic, biotic and anthropogenic factors. The basic symptoms are: yellowing, defoliation, decrease in radial increment and dying of individual trees and also groups of trees in stands of various ages, in some cases with final biotic mortality factors being present (Armillaria spp., Ips typographus, Ips duplicatus, Pityogenes chalcographus, etc.), in other cases without identifiable mortality factors.

The signs of dying grew stronger after 2003. As this was a very dry year, a hypothesis was created that within the complex of factors the climate plays a role of high or even essential importance, in other words, that the climate plays an essential role in the increase in the stress load after 2003 and to a great extent it initiates the above described decline. 
The objective of the study was to find out the dynamics of the radial growth in the Jablunkov district of the Silesian Beskids during the last 45 years, i.e. in the period for which the relevant climatic data is available, and to identify the growth responses to the climate; further, to put the knowledge gained from the tree-ring chronology in connection with the data gained concurrently regarding the health condition and the process of dying of Picea abies with the aim to confirm or deny the above mentioned hypothesis about the significance of climatic factors.

\section{MATERIAL AND METHODS}

The research was conducted in selected spruce stands of the Silesian Beskids (Fig. 1) aged over 70 at altitudes from $403 \mathrm{~m}$ a.s.l. to $794 \mathrm{~m}$ a.s.l. in 2008. The dendrochronological analysis and habitual diagnostics were carried out in the first three districts (Nýdek, Písek, Horní Lomná); the other districts were only used for habitual diagnostics. In total, 270 samples were taken for the dendrochronological analysis. There were 378 trees selected for habitual diagnostics (Table 1).

The samples were taken using the Pressler borer and processed in correspondence with the standard dendrochronological methodology (Cook and Kairiukstis, 1990). Bore holes were made at $1.3 \mathrm{~m}$ above the ground. The sampling was conducted along the contour line so that the increment could not be influenced by the presence of compression wood. At each of the plots, 30 samples were taken for dendrochronological analyses (in total 270 samples), one sample from each tree. The samples were fixed into wooden slats and their surface was ground off. The wood samples were then measured using a specialized measuring table equipped with an adjustable screw device and an impulsemeter recording the interval of table top shifting and in this way also the tree ring width. Measuring and synchronizing of tree-ring sequences were carried out using the PAST4 (CSciem) application. The annual wood increments were measured with $0.01 \mathrm{~mm}$ accuracy.

After measuring a comparison (cross-dating) of individual measured curves was made. Cross-dating is finding the synchronous positions of two tree-ring series. Both series are compared in all possible mutual positions. The aim is to identify the tree rings in each sample created in the same year. If there is a synchronous position, it is demonstrated by a sufficiently high similarity in the area where they overlap (Cook and Kairiukstis, 1990). The excellently correlating curves were used to create the average tree-ring curve. The curve sets off the common

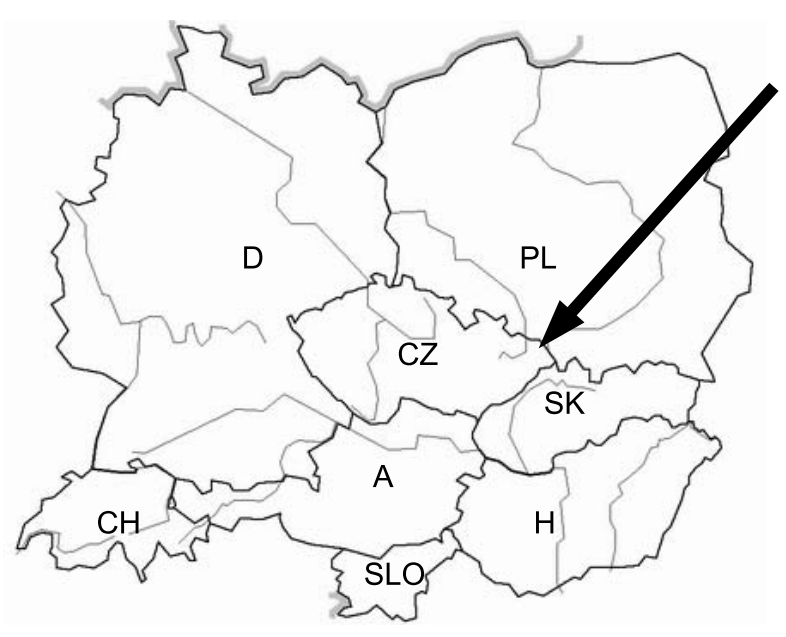

Fig. 1. Silesian Beskids

Table 1. A detailed overview of all areas

\begin{tabular}{|c|c|c|c|c|c|c|c|c|c|}
\hline \multirow{2}{*}{$\begin{array}{l}\text { Forest district } \\
\text { Title of plot }\end{array}$} & \multicolumn{3}{|c|}{ Nýdek } & \multicolumn{4}{|c|}{ Písek } & \multicolumn{2}{|c|}{ Horní Lomná } \\
\hline & N1 & N2 & N3 & P1 & P2 & P3 & P4 & HL1 & HL2 \\
\hline Number of trees & 30 & 30 & 30 & 30 & 30 & 30 & 30 & 30 & 30 \\
\hline Forest vegetation zone & 5 & 5 & 5 & 5 & 5 & 5 & 5 & 5 & 5 \\
\hline Edaphic category & mesotrophica & $\begin{array}{c}\text { lapidosa } \\
\text { mesotrophica }\end{array}$ & mesotrophica & $\begin{array}{c}\text { lapidosa } \\
\text { mesotrophica, } \\
\text { mesotrophica }\end{array}$ & $\begin{array}{c}\text { lapidosa } \\
\text { mesotrophica, } \\
\text { lapidosa } \\
\text { acidophila }\end{array}$ & mesotrophica & mesotrophica & $\begin{array}{c}\text { lapidosa } \\
\text { mesotrophica, } \\
\text { mesotrophica }\end{array}$ & mesotrophica \\
\hline GPS & $\begin{array}{l}\text { N } 49^{\circ} 40,879 \\
\text { E } 18^{\circ} 46,984\end{array}$ & $\begin{array}{l}\text { N } 49^{\circ} 40,177 \\
\text { E } 18^{\circ} 47,036\end{array}$ & $\begin{array}{l}\text { N } 49^{\circ} 39,709 \\
\text { E } 18^{\circ} 48,030\end{array}$ & $\begin{array}{l}\text { N } 49^{\circ} 34,709 \\
\text { E } 18^{\circ} 48,951\end{array}$ & $\begin{array}{l}\text { N } 49^{\circ} 39,709 \\
\text { E } 18^{\circ} 48,032\end{array}$ & $\begin{array}{l}\text { N } 49^{\circ} 34,304 \\
\text { E } 18^{\circ} 49,964\end{array}$ & $\begin{array}{l}\text { N } 49^{\circ} 35,551 \\
\text { E } 18^{\circ} 48,973\end{array}$ & $\begin{array}{l}\text { N } 49^{\circ} 30,422 \\
\text { E } 18^{\circ} 38,367\end{array}$ & $\begin{array}{l}\text { N } 49^{\circ} 35,551 \\
\text { E } 18^{\circ} 48,975\end{array}$ \\
\hline Altitude (m a.s.I.) & 778 & 673 & 601 & 650 & 753 & 549 & 759 & 765 & 794 \\
\hline Slope orientation & SW $225^{\circ}$ & NW $315^{\circ}$ & $\mathrm{S} 180^{\circ}$ & $\mathrm{NE} 45^{\circ}$ & SW $225^{\circ}$ & SW $225^{\circ}$ & SW $225^{\circ}$ & SE $135^{\circ}$ & NW $315^{\circ}$ \\
\hline Forest district & \multicolumn{4}{|c|}{ Mosty u Jablunkova } & \multicolumn{3}{|c|}{ Dolní Lomná } & \multicolumn{2}{|c|}{ Rovina } \\
\hline Title of plot & M1 & M2 & M3 & M4 & DL1 & DL2 & DL3 & R1 & R2 \\
\hline Number of trees & 12 & 12 & 12 & 12 & 12 & 12 & 12 & 12 & 12 \\
\hline Forest vegetation zone & 5 & 5 & 5 & 5 & 5 & 4 & 5 & 4 & 4 \\
\hline Edaphic category & $\begin{array}{c}\text { mesotrophica, } \\
\text { acidophila }\end{array}$ & mesotrophica & acidophila & mesotrophica & trophica & mesotrophica & $\begin{array}{c}\text { illimerosa } \\
\text { trophica }\end{array}$ & $\begin{array}{c}\text { variohumida } \\
\text { mesotrophica }\end{array}$ & $\begin{array}{c}\text { variohumida } \\
\text { mesotrophica }\end{array}$ \\
\hline GPS & $\begin{array}{l}\text { N } 49^{\circ} 30,635 \\
\text { E } 18^{\circ} 44,493 \\
\end{array}$ & $\begin{array}{l}\mathrm{N} 49^{\circ} 31,101 \\
\mathrm{E} 18^{\circ} 44,408 \\
\end{array}$ & $\begin{array}{l}\text { N } 49^{\circ} 30,569 \\
\text { E } 18^{\circ} 43,562 \\
\end{array}$ & $\begin{array}{l}\text { N } 49^{\circ} 30,730 \\
\text { E } 18^{\circ} 43,361 \\
\end{array}$ & $\begin{array}{l}\text { N } 49^{\circ} 31,462 \\
\text { E } 18^{\circ} 42,429 \\
\end{array}$ & $\begin{array}{l}\text { N } 49^{\circ} 31,552 \\
\text { E } 18^{\circ} 44,460 \\
\end{array}$ & $\begin{array}{l}\text { N } 49^{\circ} 31,642 \\
\text { E } 18^{\circ} 44,225 \\
\end{array}$ & \begin{tabular}{|l} 
N $49^{\circ} 36,267$ \\
E $18^{\circ} 43,420$ \\
\end{tabular} & $\begin{array}{l}\mathrm{N} 49^{\circ} 36,822 \\
\mathrm{E} 18^{\circ} 42,180 \\
\end{array}$ \\
\hline Altitude (m a.s.I.) & 666 & 706 & 726 & 757 & 725 & 607 & 648 & 403 & 418 \\
\hline Slope orientation & $\mathrm{S} 180^{\circ}$ & $\mathrm{E} 80^{\circ}$ & W $270^{\circ}$ & ESE $115^{\circ}$ & EEN $80^{\circ}$ & NEE $60^{\circ}$ & $\mathrm{E} 90^{\circ}$ & $\mathrm{N} 340^{\circ}$ & $\mathrm{N} 230^{\circ}$ \\
\hline
\end{tabular}


extremes related to climatic changes and reduces all the other oscillations caused by other factors. The degree of similarity between the tree-ring curves was evaluated using the correlation coefficient and the parallelism coefficient (Gleichläufigkeit). These calculations facilitate the optical comparison of both curves, which is crucial for the final dating (Rybníček et al., 2010).

Individual tree-ring series were exported from PAST4 to the ARSTAN application (Grissino-Mayer et al., 1992), where they were detrended, autocorrelation was removed and the regional standard tree-ring chronology and the regional residual tree-ring chronology were created. The removal of the age trend was carried out using a two-step detrending method (Holmes et al., 1986). First, a negative exponential function or a linear regression curve, which best express the change of the growth trend with age, were used (Fritts et al., 1969). Other potentially non-climatically conditioned fluctuations of values of radial increments, brought about by e.g. competition or forester's interference, were balanced using the cubic spline function (Cook and Peters, 1981). The chosen length of the spline function was $67 \%$ of the detrended tree-ring curve length (Cook and Kairiukstis, 1990).

From the tree-ring series detrended in this way the regional index residual tree-ring chronology was created in the ARSTAN application. The chronology has low values of autocorrelation. Also the standard regional tree-ring chronology was established. The range of the created regional tree-ring chronologies is from 1886 to 2007.

To model the radial increments in dependence on the climatic characteristics the DendroClim application was used (Biondi and Waikul, 2004). Before the modelling itself it was necessary to convert the output data from ARSTAN to the input format of DendroClim.

The regional index residual tree-ring chronology and the climatic time series of average monthly temperatures and precipitation for the Silesian Beskids were used to calculate the correlations of values of radial increments with climatic factors. The climatic time series of average monthly temperatures and precipitation was built from Jablunkov meteorological station data ( $\mathrm{N} 49^{\circ} 35^{\prime} 38.04$; E $18^{\circ} 44^{\prime} 39.12$ ). The series covers the period from 1961 to 2007. They were always calculated from May of the previous year till August of the year in question, i.e. the period of 16 months. It is the period that should have the highest influence on the radial increments in that particular year.

The statistical comparison of time series of radial increments and the time series of climatic factors will enable us to find out what the average influence of the studied climatic parameters on the increments is in the long term. The influences that occur with a low frequency and that also have fundamental effect on the tree growth do not have to be demonstrated in the correlation analysis to a statistically significant degree (Kienast et al., 1987). To establish these effects the analysis of negative pointer years was used. The negative pointer year is defined as an extremely narrow tree ring with the growth reduction exceeding $40 \%$ in comparison with the average tree-ring width in the four previous years; strong increment reduction was found in at least $20 \%$ of the trees from the area (Kroupová, 2002).
In the habitual diagnostics the following were especially evaluated: the total defoliation, the defoliation of the primary structure, the percentage of secondary shoots, the presence and extent of yellowing and the browning, and the stem damage (Cudlín et al., 2001).

In the representative number of trees basic habitual characteristics according to Cudlín et al. (2001) were evaluated by means of binoculars. First, the growth habit of a tree was described, namely, social position, type of branching, type of the tree top, crown form, the presence of stem, crown and top breaks. Crowns were visually divided to three parts: upper juvenile part, central production part and lower saturation part. In the juvenile part, its form was evaluated (according to the modified method of Lesinski and Landman (1995)), in the production part, total defoliation, defoliation of the primary structure, the percentage of secondary shoots and types of damage (Cudlín et al., 2001). Subsequently, discoloration was assessed, i.e. yellowing and browning - the percentage was estimated of the total volume of an assimilatory apparatus with the presence of discoloration (in an interval of $5 \%$ ).

To be able to assess the extent of spruce decline in the region relevantly, including its mortality, the data on salvage cutting occurrences were collected for the period from 1999 to 2008 . The data were acquired from the Forest Economy Records and then processed. The forestry records used two categories for the cuttings connected with the described unspecific decline of spruce: "dead trees without attack" and "salvage cutting, tracheomycosis (Armillaria spp.)”.

\section{RESULTS}

When comparing the average tree-ring curves of the individual districts, the statistical indicators show high values. When the curves overlap by at least sixty rings, the critical value of Student's t-distribution with $0.1 \%$ level of significance is 3.46 (Šmelko and Wolf, 1977). The values of our t-tests are much higher than 3.46, which show a high reliability of the synchronization (Table 2). The correctness of the synchronization is also proved by the agreement of the average tree-ring curves in most of the extreme values (Fig. 2). Thanks to these results, only one average tree-ring curve representing the radial increment of all three districts together could be created.

Table 2. Synchronization of average tree-ring curves of individual district

\begin{tabular}{cccc}
\hline $\begin{array}{c}\text { Compared } \\
\text { curves }\end{array}$ & $\begin{array}{c}\text { T-test (ac- } \\
\text { cording to } \\
\text { Baillie \& } \\
\text { Pilcher) }\end{array}$ & $\begin{array}{c}\text { T-test } \\
\text { (according } \\
\text { to Holl- } \\
\text { stein) }\end{array}$ & $\begin{array}{c}\text { Gleichläufigkeit } \\
\text { (\%) }\end{array}$ \\
\hline $\begin{array}{c}\text { Nýdek x } \\
\text { Písek }\end{array}$ & 16.27 & 16.12 & 77 \\
\hline $\begin{array}{c}\text { Nýdek x } \\
\text { Horní } \\
\text { Lomná }\end{array}$ & 10.18 & 9.21 & 69 \\
\hline $\begin{array}{c}\text { Písek x } \\
\text { Horní } \\
\text { Lomná }\end{array}$ & 15.03 & 12.6 & 76 \\
\hline
\end{tabular}




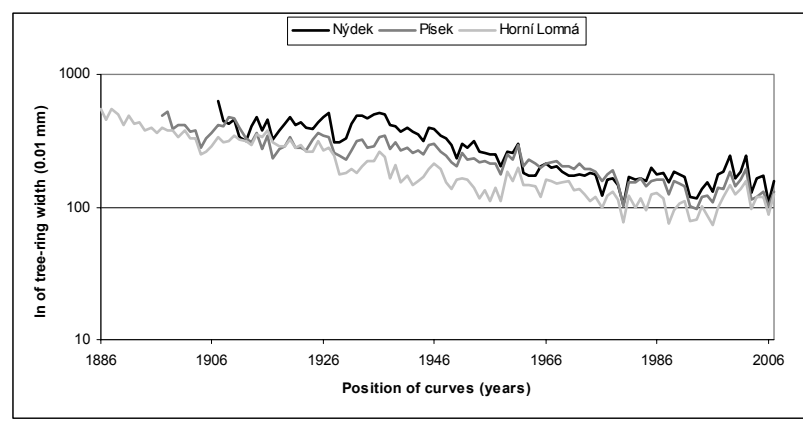

Fig. 2. Synchronization of average tree-ring curves of individual district

The correlations of the radial increment with average monthly temperatures and precipitation have only positive statistically significant values. The radial increment statistically significantly correlates with temperatures in October of the previous years and in March of the year in question (Fig. 3). The correlation of the radial increment with temperatures of the vegetation period (AprilSeptember) either of the previous year or the year in question shows no statistically significant values. The growth of spruce is statistically significantly affected by the precipitation in July and September of the previous year and the precipitation in June of that particular year (Fig. 4). The comparison of the radial increment with the precipitation within the vegetation period of the previous year and the year in question, and also with a three-month period (July, August, September) of the previous year shows statistically significant correlations.

To establish the correlations between the radial increment and monthly values of temperatures and precipitation in particular years the moving response analysis (Biondi, 1997) was chosen. Due to the relatively short temporal climatic series (1961-2007) it was only possible to calculate the correlations for the period from 1995 to 2006. The DendroClim application requires that the minimal length of the intervals (moving intervals) is a double of predictors (17 in our case); therefore, the minimal possible interval of 34 years was selected.

The most statistically significant seems to be the positive correlation between the radial increment and temperatures in October of the previous year (starting in 2001) and mainly in March of the year in question for the entire period analysed. Also the negative correlation in

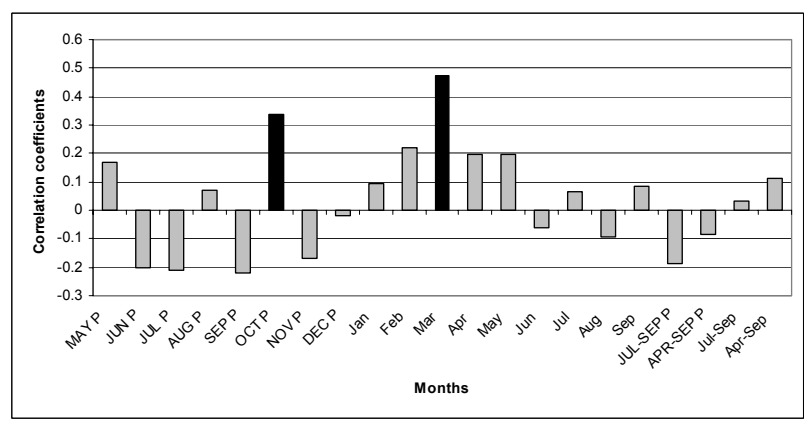

Fig. 3. The values of correlation coefficients of the regional residual index tree-ring chronology with the average monthly temperatures from May of the previous year $(P)$ to September of the year in question; moreover, the period of July-September of both the previous year $(P)$ and the year in question and the vegetation period (April-September) of both the previous $(P)$ year and the year in question were added for the period of 1962-2006. Values highlighted in black are statistically significant $(\alpha=0.05)$.

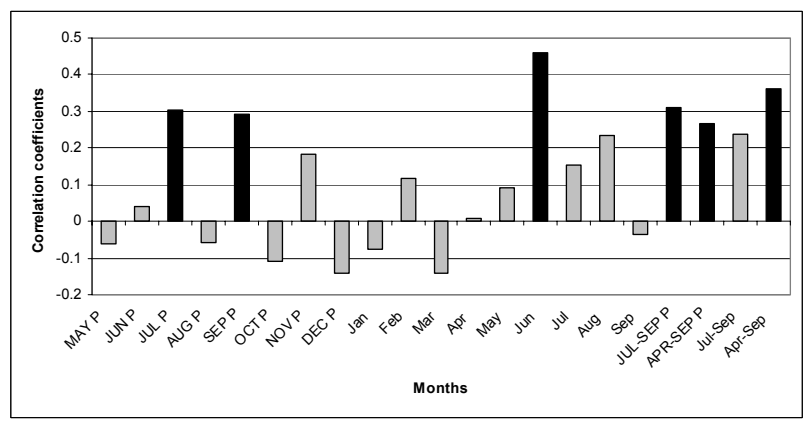

Fig. 4. The values of correlation coefficients of the regional residual index tree-ring chronology with the average monthly precipitations from May of the previous year $(P)$ to September of the year in question; moreover, the period of July-September of both the previous $(P)$ year and the year in question and the vegetation period (April-September) of both the previous year $(P)$ and the year in question were added for the period of 1962-2006. Values highlighted in black are statistically significant $(\alpha=0.05)$.

June until 1998 is highly interesting. The other correlations do not present any longer tendency (Table 3).

The precipitation presents, with one exception, only positive statistically significant correlations, only during the vegetation period. The correlations in July, August

Table 3. The values of correlation coefficients for moving response of the regional residual index tree-ring chronology with the average monthly temperatures from May of the previous year $(P)$ to September of the year in question for the period of 1962-2006. Values highlighted in black (negative correlation) and grey (positive correlation) are statistically significant $(\alpha=0.05)$, moving intervals were used with the base length of 34 years over.

\begin{tabular}{|c|c|c|c|c|c|c|c|c|c|c|c|c|c|c|c|c|c|}
\hline & MAYP & JUN P & JUL P & AUG P & SEP P & OCT P & NOVP & DEC P & Jan & Feb & Mar & Apr & May & Jun & Jul & Aug & Sep \\
\hline 1995 & 0.218 & -0.371 & -0.162 & -0.125 & -0.3 & 0.26 & -0.071 & 0.081 & -0.133 & 0.005 & 0.417 & 0.203 & 0.206 & 0.076 & -0.018 & -0.168 & 0.101 \\
\hline 1996 & 0.185 & -0.348 & -0.299 & -0.127 & -0.226 & 0.259 & -0.003 & 0.037 & -0.069 & 0.028 & 0.418 & 0.276 & 0.098 & -0.048 & -0.029 & -0.136 & 0.165 \\
\hline 1997 & 0.188 & -0.354 & -0.329 & -0.117 & -0.264 & 0.263 & 0.01 & -0.002 & -0.112 & 0.035 & 0.431 & 0.229 & 0.119 & -0.018 & -0.042 & -0.122 & 0.174 \\
\hline 1998 & 0.202 & -0.315 & -0.327 & -0.082 & -0.258 & 0.234 & 0.034 & 0 & -0.103 & 0.045 & 0.42 & 0.249 & 0.121 & 0.025 & -0.019 & -0.127 & 0.175 \\
\hline 1999 & 0.222 & -0.098 & -0.213 & -0.028 & -0.19 & 0.219 & -0.133 & -0.058 & -0.007 & 0.004 & 0.428 & 0.332 & 0.093 & 0.057 & 0.059 & -0.16 & 0.3 \\
\hline 2000 & 0.264 & -0.119 & -0.215 & -0.001 & -0.207 & 0.249 & -0.1 & -0.077 & 0.028 & -0.021 & 0.437 & 0.274 & 0.085 & 0.048 & 0.082 & -0.148 & 0.314 \\
\hline 2001 & 0.305 & -0.069 & -0.215 & 0.07 & -0.232 & 0.308 & -0.015 & -0.034 & 0.031 & -0.015 & 0.432 & 0.274 & 0.118 & 0.001 & 0.082 & -0.114 & 0.252 \\
\hline 2002 & 0.316 & -0.157 & -0.163 & 0.147 & -0.283 & 0.392 & -0.109 & -0.184 & 0.045 & 0.093 & 0.461 & 0.266 & 0.255 & 0.088 & 0.216 & 0.035 & 0.16 \\
\hline 2003 & 0.187 & -0.213 & -0.24 & 0.077 & -0.231 & 0.412 & -0.171 & -0.109 & 0.066 & 0.155 & 0.456 & 0.263 & 0.175 & -0.068 & 0.152 & -0.09 & 0.132 \\
\hline 2004 & 0.171 & -0.203 & -0.242 & 0.049 & -0.235 & 0.396 & -0.173 & -0.116 & 0.063 & 0.157 & 0.465 & 0.24 & 0.171 & -0.052 & 0.152 & -0.097 & 0.139 \\
\hline 2005 & 0.178 & -0.2 & -0.238 & 0.074 & -0.229 & 0.41 & -0.167 & -0.116 & 0.067 & 0.148 & 0.454 & 0.26 & 0.189 & -0.06 & 0.167 & -0.099 & 0.152 \\
\hline 2006 & 0.137 & -0.186 & -0.257 & 0.085 & -0.235 & 0.41 & -0.159 & -0.11 & 0.141 & 0.158 & 0.475 & 0.218 & 0.192 & -0.135 & 0.057 & -0.067 & 0.106 \\
\hline
\end{tabular}


and September of the previous year and in June of the year in question are of essential importance. The June correlations of the year in question are statistically significant during the entire explored period, while statistically significant correlations of the previous year occur in some years only (Table 4).

The regional standard tree-ring chronology shows an obvious decrease in the radial increment in the second half of the 1970s and the beginning of the 1980s. The lowest values of increment are found for years 1976, 1980, 1988, 1992, and 1993. These years with low increment were also confirmed by the analysis of significant negative years (Table 5). Starting in 1996 there is an obvious increase in increments which is interrupted only in 2000. Another decrease comes in 2003 and 2006 (Fig. 5). The results of the analysis of the significant negative years show that the highest growth depressions were in 1980 and 2003, when $60-80 \%$ of all trees responded in this way. The possible explanations for the low increments in particular negative years are presented in Table 5.

The results of the habitual diagnostics from the explored area were confronted with the results from other mountain ranges of the Czech Republic (Table 6). The table shows the very low percentage of secondary shoots and low degree of crown transformation. This also corresponds with the little representation of resilient trees and damaged, heavily transformed trees (Fig. 6).

The development of salvage cutting connected with the observed decline is presented in Fig. 7. The graph shows the first cutting in 2001, therefore, we can conclude that the stress factor or factors started to gain their

Table 4. The values of correlation coefficients for moving response intervals of the regional residual index tree-ring chronology with the average monthly precipitations from May of the previous year $(P)$ to September of the year in question for the period of 1962-2006. Values highlighted in black (negative correlation) and grey (positive correlation) are statistically significant $(\alpha=0.05)$, moving intervals were used with the base length of 34 years over.

\begin{tabular}{|c|c|c|c|c|c|c|c|c|c|c|c|c|c|c|c|c|c|}
\hline & MAY P & JUN P & JUL P & AUG P & SEP P & OCT P & NOV P & DEC P & Jan & Feb & Mar & Apr & May & Jun & Jul & Aug & Sep \\
\hline 1995 & 0.161 & -0.038 & 0.207 & 0.337 & 0.184 & -0.254 & 0.091 & -0.074 & -0.015 & -0.058 & -0.133 & 0.129 & 0.217 & 0.307 & 0.14 & 0.346 & -0.143 \\
\hline 1996 & 0.123 & 0.02 & 0.26 & 0.286 & 0.102 & -0.189 & 0.038 & 0.005 & 0.04 & -0.01 & -0.071 & 0.133 & 0.263 & 0.316 & 0.113 & 0.255 & -0.303 \\
\hline 1997 & 0.149 & 0.004 & 0.23 & 0.294 & 0.155 & -0.192 & 0.073 & -0.02 & 0.013 & -0.029 & -0.087 & 0.14 & 0.291 & 0.309 & 0.166 & 0.254 & -0.314 \\
\hline 1998 & 0.187 & -0.012 & 0.245 & 0.281 & 0.163 & -0.179 & 0.088 & -0.021 & 0 & -0.023 & -0.078 & 0.123 & 0.287 & 0.309 & 0.139 & 0.226 & -0.269 \\
\hline 1999 & 0.113 & 0.039 & 0.171 & 0.134 & 0.248 & -0.065 & 0.077 & -0.085 & -0.061 & 0.041 & -0.104 & 0.086 & 0.212 & 0.455 & 0.089 & 0.085 & -0.327 \\
\hline 2000 & 0.095 & -0.01 & 0.178 & 0.149 & 0.254 & -0.046 & 0.084 & -0.075 & -0.048 & 0.024 & -0.126 & 0.088 & 0.199 & 0.444 & 0.062 & 0.079 & -0.311 \\
\hline 2001 & 0.06 & -0.063 & 0.229 & 0.092 & 0.256 & -0.064 & 0.081 & -0.093 & -0.044 & 0.034 & -0.13 & 0.121 & 0.174 & 0.47 & 0.099 & 0.06 & -0.224 \\
\hline 2002 & -0.008 & 0.035 & 0.315 & 0.028 & 0.355 & -0.135 & 0.16 & -0.088 & -0.075 & 0.115 & -0.112 & -0.019 & 0.235 & 0.441 & 0.064 & 0.174 & -0.144 \\
\hline 2003 & -0.065 & 0.012 & 0.315 & -0.066 & 0.293 & -0.179 & 0.178 & -0.059 & -0.091 & 0.157 & -0.113 & 0.024 & 0.203 & 0.507 & 0.049 & 0.241 & -0.098 \\
\hline 2004 & -0.063 & 0.022 & 0.319 & -0.042 & 0.306 & -0.174 & 0.191 & -0.058 & -0.087 & 0.138 & -0.124 & 0.025 & 0.208 & 0.502 & 0.054 & 0.241 & -0.083 \\
\hline 2005 & -0.079 & 0.017 & 0.32 & -0.064 & 0.297 & -0.18 & 0.196 & -0.071 & -0.085 & 0.171 & -0.122 & 0.003 & 0.211 & 0.499 & 0.055 & 0.241 & -0.11 \\
\hline 2006 & -0.095 & 0.058 & 0.342 & -0.09 & 0.335 & -0.112 & 0.192 & -0.198 & -0.095 & 0.177 & -0.133 & -0.07 & 0.192 & 0.515 & 0.101 & 0.197 & -0.041 \\
\hline
\end{tabular}

Table 5. Negative pointer years and climatic characteristics which may be interpretation of the years. White field, black number $-20-40 \%$ of trees sampled; grey field, black number - $40-60 \%$ of trees sampled; black field, white number $-60-80 \%$ of trees sampled.

\begin{tabular}{ll}
\hline $\begin{array}{l}\text { Negative } \\
\text { pointer } \\
\text { year }\end{array}$ & Abnormal climatic characteristics \\
\hline 1962 & without abnormal climatic characteristics \\
\hline 1963 & $\begin{array}{l}\text { high temperatures in July, low precipitation from Janu- } \\
\text { ary to April }\end{array}$ \\
\hline 1965 & $\begin{array}{l}\text { subnormal temperature in April, low precipitation in } \\
\text { March }\end{array}$ \\
\hline 1976 & $\begin{array}{l}\text { low temperatures in March, subnormal precipitation in } \\
\text { March and April }\end{array}$ \\
\hline 1980 & $\begin{array}{l}\text { low temperatures from March to May, subnormal } \\
\text { precipitation in March and May }\end{array}$ \\
\hline 1988 & low temperatures in March \\
\hline 1992 & $\begin{array}{l}\text { high temperatures from June to August, low precipita- } \\
\text { tion from May to August }\end{array}$ \\
\hline 2003 & low precipitation from April to May \\
\hline 2004 & $\begin{array}{l}\text { high temperatures in June and August, } \\
\text { low precipitation in February, April, May, June, August }\end{array}$ \\
\hline 2006 & $\begin{array}{l}\text { subnormal precipitation from April to May } \\
\text { high temperatures in June and July, low precipitation in } \\
\text { July }\end{array}$ \\
\hline
\end{tabular}

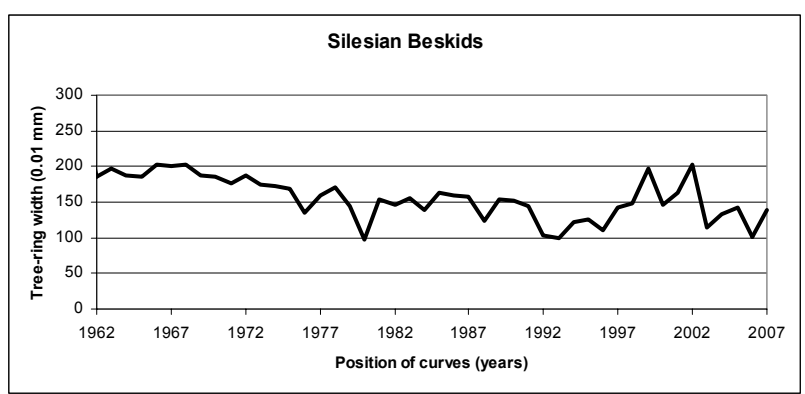

Fig. 5. Regional standard chronology from the Silesian Beskids

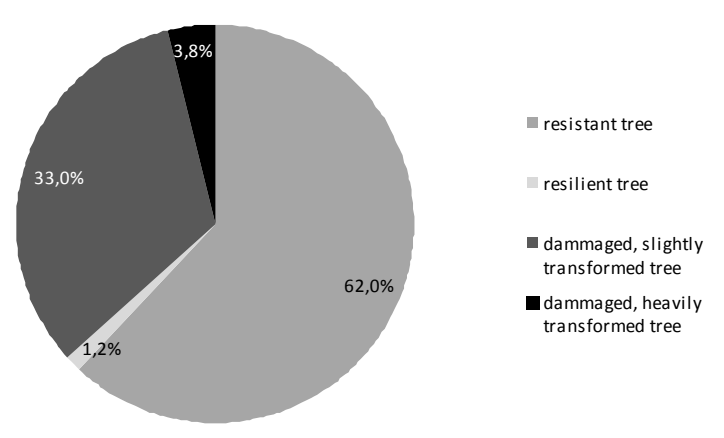

Fig. 6. The distribution of categories of tree stress response in the explored area 
mortality effect in this or the previous year (dead trees are felled with some delay).

\section{DISCUSSION AND CONCLUSIONS}

The curves of the regional standard chronology are characterized by the constant decrease in radial increment (Fig. 5). There are noticeable growth depressions, especially in the second half of the 1970s and at the beginning of the 1980s. After 1996 there is a steep rise of the increment, which is interrupted in 2000. A two-year period of increased radial increment follows, interrupted again in 2003 and 2006. After 2003 the increments did not achieve the values from the turn of the millennium. The regional standard chronologies presented in this study confirm the existing knowledge about the increment of now adult stands of Picea abies in the Beskids. The same tendency, in basic features, was found out by Feliksik and Wilczyński (2000), Wilczyński and Feliksik (2005), both in the Polish Western Beskids and Srámek et al. (2008) in the same area as was examined in this study.

The radial increment of spruce in forest district Jablunkov correlates significantly with precipitation rather than temperatures, which is an expected result. The area of the Silesian Beskids, as well as the entire Central

Table 6. The comparison of results (average values) of habitual monitoring (according to Cudlin et al., 2001) from various mountain ranges of the Czech Republic

\begin{tabular}{|c|c|c|c|c|c|c|c|}
\hline Monitoring area & 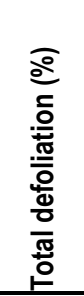 & 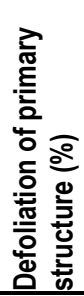 & 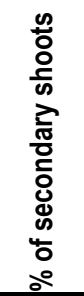 & 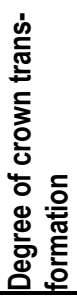 & 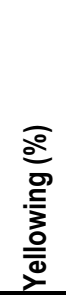 & 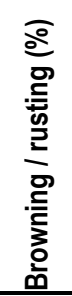 & 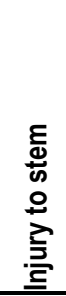 \\
\hline $\begin{array}{l}\text { Slezské Beskydy - } \\
\text { Silesian Beskids }\end{array}$ & 35.06 & 52.32 & 26.82 & 0.62 & 1.98 & 0.20 & 0.41 \\
\hline Drahanská vrchovina & & & & & & & \\
\hline $\begin{array}{l}\text { Highlands } \\
\text { (unpublished) }\end{array}$ & 36.47 & 59.83 & 36.58 & 0.95 & 0.00 & 0.00 & 0.15 \\
\hline $\begin{array}{l}\text { Orlické hory Mts. } \\
\text { (Žid et al., 2007) }\end{array}$ & 38.86 & 65.84 & 44.39 & 1.27 & 2.44 & 1.84 & 0.68 \\
\hline $\begin{array}{l}\text { Krušné hory Mts. } \\
\text { (unpublished) }\end{array}$ & 31.25 & 59.25 & 29.50 & 0.88 & - & - & - \\
\hline $\begin{array}{l}\text { Krkonoše Mts. } \\
\text { (Cudlín et al., 2001) }\end{array}$ & 45.00 & 84.33 & 76.33 & 2.88 & - & - & - \\
\hline
\end{tabular}

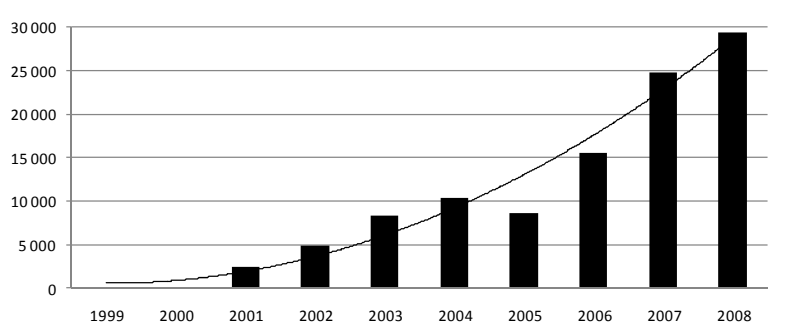

Fig. 7. The development of salvage cuttings connected with the decline of Picea abies in Forest District Jablunkov $\left(\mathrm{m}^{3}\right)$ with a polynomial trend line
Europe except peak sections of higher mountain ranges, presents no temperature-related problems for the spruce. The precipitation more often falls to the critical values, therefore it correlates with the increment more closely (Mäkinen et al., 2002). The ring width correlated positively with monthly precipitation in July and September of the previous year (Fig. 4). Positive correlation was also found with the precipitation during the vegetation period, i.e. April-September, and during summer, i.e. JulySeptember (Fig. 4). In particular years, the growth correlated significantly with precipitation in the months of July, August, September (Table 4); the character of the distribution of these correlations in particular years indicates that the determining period is the period of JulySeptember as a whole. The positive influence of precipitation in the vegetation period of the year preceding the ring growth was also documented for spruce in forest district Bukowiec (Feliksik, 1993); the positive influence of precipitation in June-July is mentioned by Pichler and Oberhuber (2007). The probable explanation for the correlation is the positive influence of this precipitation on the production of nutrients, which are then used for the growth in the initial stage of ring creation. The precipitation during the vegetation period of the preceding year, especially the end of the season, also influences the disposable water in the soil in spring.

Further, the ring width is positively correlated with monthly precipitation in June of the year when the ring was created, and with the precipitation during the vegetation period (Fig. 4). Positive correlations of precipitation in June and July are documented for the Polish part of the Beskids (leśnictwo Pierściec) by Feliksik et al. (1994). Similar results were found at other sites as well. Vitas (2004) from drier locations in Lithuania and Mäkinen et al. (2001) from the south of Finland give evidence on the correlation of the radial growth of spruce with June precipitation. Koprowski and Zielski (2006) in the north of Poland and Desplanque et al. (1999) in lower altitudes of the French Alps found correlations with precipitation of May-July. The substantial part of a tree ring in the Beskids is formed from May to July, therefore, the comfortable supply of water is of high positive significance, the key month being definitely June. The influence of spring and early summer precipitation has been rising in the last about 10 or 15 years, due to the increase in solar radiation and the frequency of high temperatures (thus also the rise of evapotranspiration). This is confirmed by the values of June correlation coefficients for individual years, or their increase after 1998 (Table 4).

The ring width significantly correlated in the positive way with the temperature in October of the previous year (Fig. 3). The same correlation was found out in the Polish Tatras by Savva et al. (2006). Good conditions for photosynthesis may have led to a more intensive storage of carboxyhydrates and thus support the growth in the following year. The reason why this influence was considerable could also be that October average temperatures had quite a high variability ranging from $5.8^{\circ} \mathrm{C}$ to $13.3^{\circ} \mathrm{C}$ and in this way created highly variable conditions for the photosynthetic activity. A higher average temperature in October is often the consequence of a more balanced procedure of day temperatures without any steep and 
sudden decreases. Such weather allows for a more continual and gradual transition of spruce to dormancy. In individual years (Table 3) significant October correlations were found for years 2001-2006. In 2001 first larger dying of trees without any obvious signs of damage started to appear and these trees were felled in salvage cuttings (Fig. 7). It is possible that the significance of October temperatures rose in relation to the deteriorated vitality of trees. In other words, the transition of weaker trees to dormancy is more strongly connected with the sufficient supply of carboxyhydrates as their capacity to compensate for the handicap is smaller.

Moreover, the ring width is significantly positively correlated with the temperature in March of the year in question (Fig. 3). The same correlation was documented in Lithuania at various sites by Vitas (2004), in south of Poland by Koprowski and Zielski (2006), and in the Polish Tatras by Savva et al. (2006). The correlation of March temperatures with the radial increment was also found out at two sites of ICP Forests (Mze ČR, VÚLHM, 2004) in the Podbeskydská vrchovina (Lower Beskids Highlands) and the Moravskoslezské Beskydy (Moravian-Silesian Beskids). A positive influence of temperatures of March-May was also stated for the Polish part of the Beskids (Feliksik et al., 1994). In March the spruce photosynthetic capacity is revived and higher temperatures bring better conditions for this revival, e.g. the soil thaws earlier. A higher average temperature also means lower risks, e.g. a lower probability of the occurrence of night frosts and consequent damage.

Many studies, especially those from higher altitudes of mountains, established a positive correlation of the growth with temperatures in summer months, specifically mainly in May, June or July (Mäkinen et al., 2001; Savva et al., 2006; Büntgen et al., 2007). However, the examined areas of the Silesian Beskids do not show a significant correlation between the growth and the temperature in these months and in June this correlation is even negative (Fig. 3). This situation shows that : i) what is critical for the growth of spruce in these altitudes in summer is precipitation, not temperature; temperatures are significant at higher altitudes only; ii) there is a negative relation between monthly precipitation and average temperature, i.e. a colder June is also usually rainier.

The results of habitual monitoring (Table 6) show an interesting proportion of resistant trees and damaged, slightly transformed trees (Fig. 6). The degree of transformation was generally low, lower than in other mountain ranges of the CR that have been monitored (Table 6). The lower degree of the damaged assimilation apparatus replacement can point to a relatively short stress, i.e. to the first induction (signalling) stage of tree response to stress, when the loss of vitality is demonstrated and the repair ability is low. The low creation of secondary shoots can also be a consequence of the high intensity of stressors.

The total defoliation was of average degree within the context of the CR, which is seemingly in contrast to the progressive character of the decline described above. Dead and dying trees with unspecific signs of decline started to appear in the location after 2000. Typically, it was a fast procedure of health deterioration when the trees went yellow, defoliated and in some cases died within one or two vegetation periods. These dead or heavily damaged trees were removed within salvage cuttings and first recorded as "dead trees without attack", and starting in 2008 for unspecified reasons as "salvage cutting, tracheomycosis (Armillaria spp.)" disrespecting whether tracheomycosis or putrefaction, micelial fans or rhizomorphs of Armillaria spp. were present or not (Fig. 7). The rising tendency of the cuttings is obvious. Therefore, the dying trees were not recorded in the habitual monitoring as they had been felled before, in spring. In spite of that, it can be concluded that the habit of trees corresponds with the development of salvage cuttings and with the hypothesis about the strong stress load or its considerable increase in 2003 and the following years.

\section{ACKNOWLEDGEMENT}

The paper was prepared within the CR Grant Agency 404/08/P367 and 205/08/0926, the research plan of LDF MZLU in Brno, MSM 6215648902 and the Ministry of Environment of the Czech Republic VaV SP/2d1/93/07.

\section{REFERENCES}

Biondi F, 1997. Evolutionary and moving response functions in dendroclimatology. Dendrochronologia 15: 139-150.

Biondi F and Waikul K, 2004. DendroClim2002: AC++ program for statistical calibration of climate signals in tree ring chronologie. Computers and Geosciences 30(3): 303-311, DOI 10.1016/j.cageo.2003.11.004.

Büntgen U, Frank DC, Kaczka RJ, Verstege A, Zwijacz-Kozina T and Esper J, 2007. Growth responses to climate in a multi-species treering network in the Western Carpathian Tatra Mountains, Poland and Slovakia. Tree Physiology 27(5): 689-702, DOI 10.1093/treephys/27.5.689.

Cook ER and Kairiukstis LA, 1990. Methods of Dendrochronology Applications in the Environmental Sciences. Kluwer Academic Publisher and International Institute for Applied Systems Analysis, Dordrecht, Boston, London: 394pp.

Cook ER and Peters K, 1981. The smoothing spline: a new approach to standardizing forest interior tree-ring width series for dendroclimatic studies. Tree Ring Bulletin 41: 45-53.

Cudlín P, Novotný R, Moravec I and Chmelíková E, 2001. Retrospective evaluation of the response of montane forest ecosystems to multiple stress. Ekológia 20: 108-124.

Desplanque C, Rolland C and Schweingruber FH, 1999. Influence of species and abiotic factors on extreme tree ring modulation: Picea abies and Abies alba in Tarentaise and Maurienne (French Alps). Trees 13(4): 218-227, DOI 10.1007/s004680050236.

Feliksik E, 1993. Wpływ klimatu na Wielkość przyrostów radialnych lasotwórczych gatunków, występujących na terenie leśnictwa Bukowiec (The effects of climate on the radial increments of the forest tree species occurring in the Bukowiec Forest district). Acta Agraria et Silvestria, Series Silvestris 31: 39-46 (in Polish).

Feliksik E, Wilczyński S and Wałecka M, 1994. Klimatyczne uwarunkowania przyrostów kambialnych świerka pospolitego (Picea abies Karst.) w leśnictwie Pierściec (Climatic conditions of the cambial tree-rings of spruce (Picea abies Karst.) in the forest district of Pierściec). Acta Agraria et Silvestria. Series Silvestris 32: 53-59 (in Polish).

Feliksik E and Wilczyński S, 2000. Dendroclimatological analysis of the Norway spruce (Picea abies (L.) Karst.) from the Beskid Śląski Mountains. Zpravodaj Beskydy 13: 161-170.

Fritts HC, Mosimann JE and Bottorff CP, 1969. A Revised Computer Program for Standardizing Tree - Ring Series. Tree Ring Bulletin 29: 15-20.

Grissino-Mayer HD, Holmes R and Fritts HC, 1992. International treering data bank program library. Version 1.1. Laboratory of TreeRing Research, University of Arizona, Tucson. 
Holmes RL, Adams RK and Fritts HC, 1986. Tree-Ring Chronologies of Western North America: California, Eastern Oregon and Northern Great Basin with Procedures Used in the Chronology Development Work Including Users Manuals for Computer programs Cofecha and Arstan. - Chronology Series VI. Laboratory of TreeRing Research, University of Arizona, Tuscon, AZ, USA: 50-56.

Kienast F, Schweingruber FH, Bräker OU and Schär E, 1987. Tree ring studies on conifers along eco-logical gradients and the potential of single-year analyses. Canadian Journal of Forest Research 17(7): 683-696, DOI 10.1139/x87-111.

Koprowski M and Zielski A, 2006. Dendrochronology of Norway spruce (Picea abies (L.) Karst.) from two range centres in lowland Poland. Trees 20(3): 383-390, DOI 10.1007/s00468-006-0051-9.

Kroupová M, 2002. Dendroecological study of spruce growth in regions under long-term air pollution load. Journal of Forest Science 48(12): 536-548.

Lesinski JA and Landman G, 1995. Crown and branch malformation in conifers related to forest decline. In Cape JN and Mathy P, (eds.) Scientific basis of forest decline symptomatology, Air Pollution Research Report 15: 95-105.

Mäkinen H, Nöjd P and Mielikäinen K, 2000. Climatic signal in annual growth variation in damaged and healthy stands of Norway spruce (Picea abies) along a transect from central Finland to the Arctic timberline. Canadian Journal of Forest Research 30(5): 769-777, DOI 10.1139/cjfr-30-5-769.

Mäkinen H, Nöjd P and Mielikäinen K, 2001. Climatic signal in annual growth variation in damaged and healthy stands of Norway spruce [Picea abies (L.) Karst.] in southern Finland. Trees 15(3): 177-185, DOI 10.1007/s004680100089.

Mäkinen R, Nöjd P, Kahle HP, Neumann U, Tveite B, Mielikäinen K,
Röhle H and Spiecker H, 2002. Radial growth variation of Norway spruce (Picea abies (L.) Karst.) across latitudinal and altitudinal gradients in central and northern Europe. Forest Ecology and Management 171(3): 243-259, DOI 10.1016/S03781127(01)00786-1.

MZe ČR, VÚLHM 2004. Monitoring stavu lesa v České republice 1984-2003 (Forest Condition Monitoring in the Czech Republic, 1984-2003). MZe ČR, VÚLHM, Praha, 432 pp (in Czech).

Pichler $\mathrm{P}$ and Oberhuber W, 2007. Radial growth response of coniferous forest trees in an inner Alpine environment to heat-wave in 2003. Forest Ecology and Management 242(2-3): 688-699, DOI 10.1016/j.foreco.2007.02.007.

Rybníček M, Koňas P and Kolář T, 2010: The Benefits of Tree-Ring Curves Detrending for Dating Archaeological Wood. Geochronometria 35: 85-90, DOI 10.2478/v10003-010-0004-6.

Savva J, Oleksyn J, Reich PB., Tjoelker MG, Vaganov EA and Modrzynski J, 2006. Interannual growth response of Norway spruce to climate along an altitudinal gradient in the Tatra Mountains, Poland. Trees 20(6): 735-746, DOI 10.1007/s00468-0060088-9.

Šmelko Š and Wolf J, 1977. Štatistické metódy v lesníctve (Statistical Methods in Forestry). Príroda: 330pp (in Slovak).

Šrámek V, Vejpustková M, Novotný R and Hellebrandová K, 2008. Yellowing of Norway spruce stands in the Silesian Beskids - damage extent and dynamics. Journal of Forest Science 54(2): 55-63.

Vitas A, 2004. Tree rings of Norway spruce (Picea abies (L.) Karsten) in Lithuania as drought indicators: dendroecological approach. Polish Journal of Ecology 52(2): 201-210.

Wilczyński S and Feliksik E, 2005. Disturbances in variation of the annual ring width of Norway spruce in the Polish Western Beskids Mountains. Journal of Forest Science 51(12): 539-547. 